\title{
Peptide separation of commercial fermented milk during refrigerated storage
}

\author{
Luis Guillermo GONZÁLEZ-OLIVARES ${ }^{1}$, Javier AÑORVE-MORGA ${ }^{1}$, Araceli CASTAÑEDA-OVANDO ${ }^{1}$, \\ Elizabeth CONTRERAS-LÓPEZ1 ${ }^{1}$ Judith JAIMEZ-ORDAZ ${ }^{1 *}$
}

\begin{abstract}
Milk is an important source of bioactive compounds. Many of these compounds are released during fermentation and refrigerated storage. The aim of this study was to determine the release of peptides by lactic acid bacteria in commercial fermented milk during refrigerated storage. The size and profile of peptides were analyzed by polyacrylamide gel electrophoresis and sizeexclusion HPLC. During electrophoresis, it was observed that the peptides were released from caseins, whereas $\beta$-lactoglobulin was the whey protein with the highest degradation. HPLC analysis confirmed the pattern of peptide formation observed in electrophoresis. Two fractions lower than $2 \mathrm{kDa}$ with aromatic amino acids in their structure were separated. These results were consistent with those reported for structures of peptides with antihypertensive activity. Therefore, the presence of aromatic amino acids in the peptide fractions obtained increases the likelihood of finding peptides with such activity in refrigerated commercial fermented milk. In conclusion, during cold storage, peptides with different molecular weights are released and accumulated. This could be due to the action of proteinases and peptidases of the proteolytic system in lactic acid bacteria.
\end{abstract}

Keywords: bioactive peptide; fermented milk; cold storage; antihypertensive activity; lactic acid bacteria.

\section{Introduction}

Functional foods can be obtained by the addition of probiotics, prebiotics, synbiotic, or functional ingredients. Probiotics are live microorganisms that exert positive effects on health by improving the balance in the intestinal microflora of consumers (Yerlikaya, 2014; Stanton et al., 2005; Vinderola et al., 2002; Gorbach, 2000). The growth of microorganisms in the gastrointestinal tract may be stimulated by prebiotics. Prebiotics are non-digestible oligosaccharides fermentable by different species of lactic acid bacteria (LAB) (Roberfroid, 2000). Synbiotics (a combination of probiotics and prebiotics) improve survival of probiotics enhancing their effects in the large bowel (Roberfroid, 2000). Several studies have shown additional benefits of probiotics, such as the increase in immune system response and the release of bioactive compounds (Hempel et al., 2012; Bomba et al., 2012). The release of bioactive peptides from a protein sequence can be produced by enzymatic hydrolysis (Udenigwe \& Aluko, 2012; Hartmann \& Meisel, 2007), by fermentation processes (Hafeez et al., 2014; Udenigwe \& Aluko, 2012; Quirós et al., 2005), or by a combination of both and during gastrointestinal digestion of food (Saito, 2008).

Bioactive peptides are included in the group of protein ingredients which produce functional foods (Nagpal et al., 2011). Within the group of bioactive peptides, the ones that have attracted higher scientific and industrial interest are those having antihypertensive activity. Interest in studying these compounds has arisen from the increase in mortality in industrialized countries due to hypertension and/or renal, heart or brain complications (Rojas-Ronquillo et al., 2012; Contreras et al., 2009; Nielsen et al., 2009; Saito, 2008; Hartmann
\& Meisel, 2007; Quirós et al., 2005; Wu \& Ding, 2001; Takano, 1998).

Over the past few decades, fermented milks have been considered beneficial to health. This has been ascribed to the microorganisms involved in fermentation. Recent studies have proven that these benefits are also due to the different compounds released during the fermentation process, such as metabolites and other biologically active molecules (FigueroaGonzález et al., 2010). Numerous peptides with diverse biological activities have been isolated from fermented milks. The first fermented milk with proven antihypertensive activity was produced using a combination of Lactobacillus helveticus and Saccharomyces cerevisiae (Nakamura et al., 1995); the milk contained two angiotensin-converting enzyme inhibiting tripeptides (ACE). Accordingly, it has been demonstrated that different lactic bacteria (Lactobacillus, Lactococcus, and Streptococcus) are capable of producing bioactive peptides during the fermentation process and during cold storage (Phelan et al., 2009). Due to the short fermentation period during the production of fermented milks (2 to 4 hours), proteolytic activity is low. This activity represents the hydrolysis of 1 to $2 \%$ of the existing proteins, of which $80 \%$ is carried out on caseins (Meisel \& Bockelmann, 1999). However, at the end of fermentation and during refrigerated storage, BAL are capable of surviving (Vinderola et al., 2000) and their proteolytic activity is maintained (Nielsen et al., 2009). Despite the fact that the optimum temperature for the enzymes belonging to the proteolytic system of lactic bacteria ranges between 35 and $37^{\circ} \mathrm{C}$, their activity is not lost during refrigeration at $4^{\circ} \mathrm{C}$ (González-Olivares et al., 2011). During refrigeration; peptides 
are generated by the action of the enzymes associated to live bacteria present in the medium or in enzymes released after cell lysis (Nighswonger et al., 1996). Many studies, focused on strain improvement and preservation techniques, have shown the viability of probiotic bacteria in commercial fermented milk under refrigerated storage (Adhikari et al., 2000; Donkor et al., 2006; Donkor et al., 2007b). However, studies on peptide production during cold storage have merely focused on comparing proteolytic profiles at the beginning and the end of the storage period (Nielsen et al., 2009). Other studies have primarily focused on the combination of indirect measurement of microbial activity of bacteria in yogurt through proteolytic profile comparison during storage at $4{ }^{\circ} \mathrm{C}$ (Donkor et al., 2006). It has also been proven that after 28 days of refrigeration at $4^{\circ} \mathrm{C}$, the antihypertensive activity of yogurt increases from $70 \%$ to $90 \%$, as calculated from half maximal inhibitory concentration $\left(\mathrm{IC}_{50}\right)$ (Donkor et al., 2007a).

Nevertheless, there is no information on the molecular weight of peptides and the presence of aromatic amino acids in the polypeptide chains in commercial fermented milks stored under refrigeration. It has been reported that the presence of aromatic amino acids in the peptide chain contributes to the inhibitory effect of the ACE (Wu et al., 2006, Cheung et al., 1980). Therefore, the aim of this study was to determine the molecular weight and the presence of aromatic amino acids of peptides released by LAB in a commercial fermented milk stored at $4^{\circ} \mathrm{C}$ for 13 days.

\section{Materials and methods}

\subsection{Sample preparation}

Two samples (in duplicate) of two different batches of a commercial fermented milk were purchased from a convenience store; their expiration date was 15 days after the date of purchase. The commercial fermented milk was produced with Lactobacillus acidophilus and Streptococcus thermophilus. The samples were stored at $4^{\circ} \mathrm{C}$ for 13 days. Sample collection was carried out every third day, under sterile conditions. A volume of $5 \mathrm{~mL}$ of sample was used to determine the protein concentration.

For the analysis of peptides, $5 \mathrm{~mL}$ of each sample were mixed with $5 \mathrm{~mL}$ of $12 \%(\mathrm{w} / \mathrm{v})$ trichloroacetic acid in order to precipitate high molecular weight proteins (JiménezGuzmán et al., 2002). Both samples were centrifuged at 18000 rpm for 15 minutes at $4^{\circ} \mathrm{C}$ (Beckman J2-MI, IL, USA). The supernatant was cooled at $4^{\circ} \mathrm{C}$ and used for further analyses.

\section{Polyacrylamide gel electrophoresis (SDS-PAGE)}

The changes in the protein concentration in the fermented milk during cold storage were determined according to Laemmli (1970). Tris-Glycine gel with 15\% (w/v) acrylamide was used. Broad range molecular weight standards (Bio-Rad, Berkeley, CA, USA) were used. The gels were stained with Sypro Flamingo (Bio-Rad, Berkeley, CA, USA). Peptides of low molecular weight were separated by denaturing electrophoresis (Tris-tricine), as described by González-Olivares et al. (2011). These gels were analyzed using a Bio-Rad's (Berkeley, CA, USA) Gel-Doc image analyzer. A solution of $\beta$-lactoglobulin $(2 \mathrm{mg} / \mathrm{mL})$ was used to determine the concentration of peptides and proteins.

\subsection{Separation of peptides by Size exclusion HPLC}

Supernatants of fermented milks were injected on a Lab alliance HPLC system (NY, USA) using a size exclusion column (Biosep-SEC 2000 Phenomenex ${ }^{\circ}$, Torrance, CA, USA, particle size $5 \mathrm{~mm}$, pore size $145 \AA$, $300 \times 7.8 \mathrm{~mm}$ ). A phosphate buffer solution at $\mathrm{pH} 6.8$ was used as a mobile phase. The volume of the sample injected was $20 \mu \mathrm{L}$. The analysis was performed at room temperature using a flow of $0.25 \mathrm{~mL} / \mathrm{min}$ for $60 \mathrm{~min}$. Detection was performed at 210, 257, and $280 \mathrm{~nm}$ using a diode array detector (Spectra System UV 6000 LP, Providence, RI, USA).

\subsection{Statistical analysis}

All analyses were performed in triplicate. The results were analyzed by ANOVA and Tukey comparison test with a significance level of 0.05 using the SPSS Statistics 17.0 software (1993-2007 Polar Engineering and Consulting, Nikiski, AK, USA).

\section{Results and discussion}

\subsection{Protein separation by electrophoresis}

Casein concentration at the beginning of the experiment was $5.2 \mathrm{mg} / \mathrm{mL}$, and it decreased to $2.9 \mathrm{mg} / \mathrm{mL}$ at the end of the study. The concentration of $\beta$-lactoglobulin (BLG) in the whey proteins decreased more than that of $\alpha$-lactoalbumin (ALA) (Figure 1). This can be explained because caseins are the main substrate of the proteolytic system of LAB, which enables the association of the accumulation of peptides in the medium with the decrease in the concentration of caseins. Furthermore, it is known that the nitrogen source of LAB in fermented milk comes from casein degradation (Gasson \& de Vos, 1994; Savijoki et al., 2006). Moreover, even after the fermentation process is completed, LAB or at least the enzymes associated with their system maintain proteolytic activity during cold storage (Nielsen et al., 2009; Nighswonger et al., 1996). This may be due to the fact that the enzymes of the proteolytic system of $\mathrm{LAB}$ are proline-specific and there are four times more proline in the primary structure of BLG than in the structure of ALA (Savijoki et al., 2006).

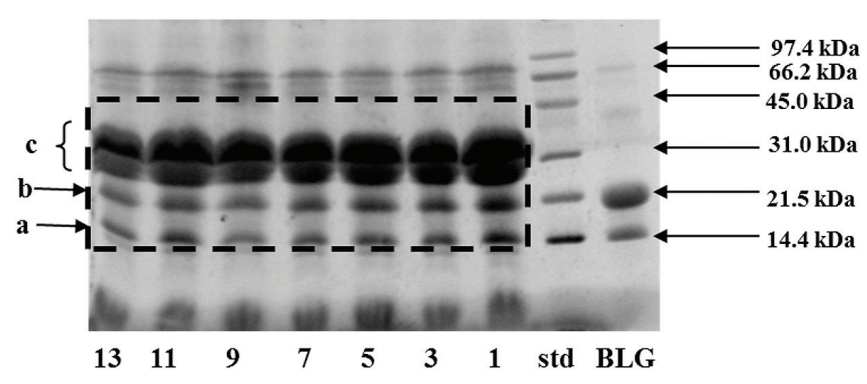

Figure 1. Proteins for commercial fermented milk during refrigerated storage $\left(4^{\circ} \mathrm{C}\right)$ in Tris-Glicine SDS-PAGE. BLG ( $\beta$-lactoglobulin); std (standard of molecular weight); numbers (1-13) refer to the day of the experiment; a: $\alpha$-lactoalbumin, b: $\beta$-lactoglobulin, c: caseins. 


\subsection{Peptide separation by electrophoresis}

Seven peptides with a molecular weight lower than $14.4 \mathrm{kDa}$ were separated and identified from day 1 of experiment. Similarly, bands of peptides of less than $1.4 \mathrm{kDa}$ were identified (Figure 2). These results have raised the expectation of finding peptides with bioactive functions in refrigerated fermented milks since it has been reported that many of these compounds have a molecular weight of less than $10 \mathrm{kDa}$ (Meisel, 2005). In addition, a decrease in the concentration of BLG and ALA with the same pattern of that found in the separation of proteins by electrophoresis was observed. Even after the preparation and refrigeration of fermented milk at $4^{\circ} \mathrm{C}$, the proteolytic activity of LAB remained active (Nielsen et al., 2009). Moreover, several authors have asserted that the concentration of peptides derived from whey proteins is higher when they are released from BLG. This is due to the fact that the proline content in BLG is four times higher than that in ALA. This is related to the specificity of proteinases and peptidases in the proteolytic system of proline-specific lactic acid bacteria (Ortiz-Chao et al., 2009; Savijoki et al., 2006).

Initial concentration of peptides was $2.4 \mathrm{mg} / \mathrm{mL}$; then there was a decrease (up to $1.8 \mathrm{mg} / \mathrm{mL}$ ) in the first 48 hours of experiment. However, from day 5 to the end of the storage period, there was a tendency to peptide concentration increase, reaching a maximum value of $2.8 \mathrm{mg} / \mathrm{mL}$. The decrease observed in the early days of storage could be due to the formation of smaller peptides from the peptides released in the fermentation by the endopeptidase action of LAB (Savijoki et al., 2006; Poolman et al., 1995). Concentration of BLG and ALA remained constant from day 7 . This could be attributed to the fact that peptides are released from caseins during fermentation and frozen storage since they are the primary substrate of enzymes belonging to the proteolytic system of LAB (Gasson \& de Vos, 1994). Donkor et al. (2007a) reported that an increase in peptide concentration in fermented milk was observed between weeks 1 and 3 of refrigerated storage, immediately after the end of the fermentation process, which is in agreement with the results obtained in this study.

\subsection{Size exclusion HPLC}

An increase in the concentration of peptides from day 5 was identified by HPLC analysis (Figure 3). Similarly, there was an increase in the number of peptides with great variability in molecular weight (mainly 6.21, 2.68, and $1.61 \mathrm{kDa}$ ) on each day of experiment. Statistical analysis showed a significant increase $(P \geq 0.05)$ in peptide concentration on day 7. However, it remained constant on days 9 and 11 , reaching its maximum value on day 13 (exceeding $250 \mathrm{mg} / \mathrm{mL}$ ). The two peptides with the highest concentration at the end of experiment were those of $2.68 \mathrm{kDa}(59.55 \mathrm{mg} / \mathrm{mL})$ and $0.87 \mathrm{kDa}(101.84 \mathrm{mg} / \mathrm{mL})$. It has been observed that during storage at $4^{\circ} \mathrm{C}$, the production of peptides is higher in culture media with some strains of $S$. thermophilus and L. acidophilus compared with other probiotics in symbiotic fermentation or when they are alone in the fermentation (Vinderola et al., 2002). The commercial fermented milk under study had microorganisms of the same species. The viability of bacteria under cooling conditions is

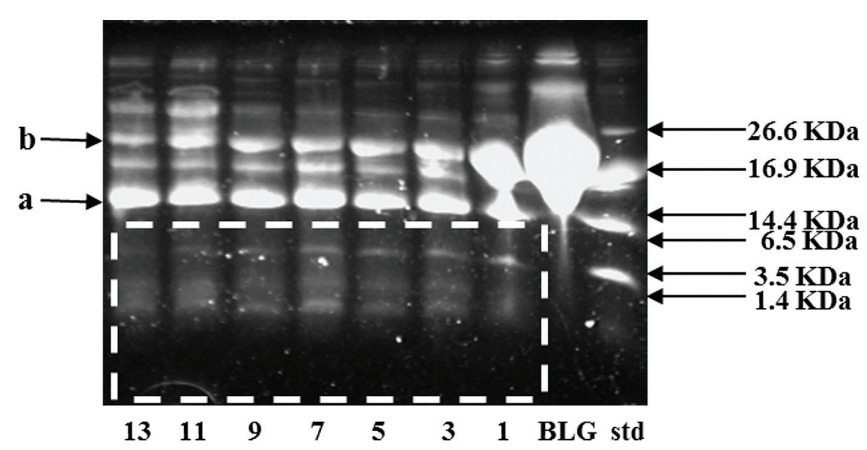

Figure 2. Peptides in commercial fermented milk during refrigerated storage $\left(4^{\circ} \mathrm{C}\right)$ in Tris-Tricine SDS-PAGE. BLG ( $\beta$-lactoglobulin); std (standard of molecular weight); numbers (1-13) refer to the day of experiment. a: $\alpha$-lactoalbumin, b: $\beta$-lactoglobulin.

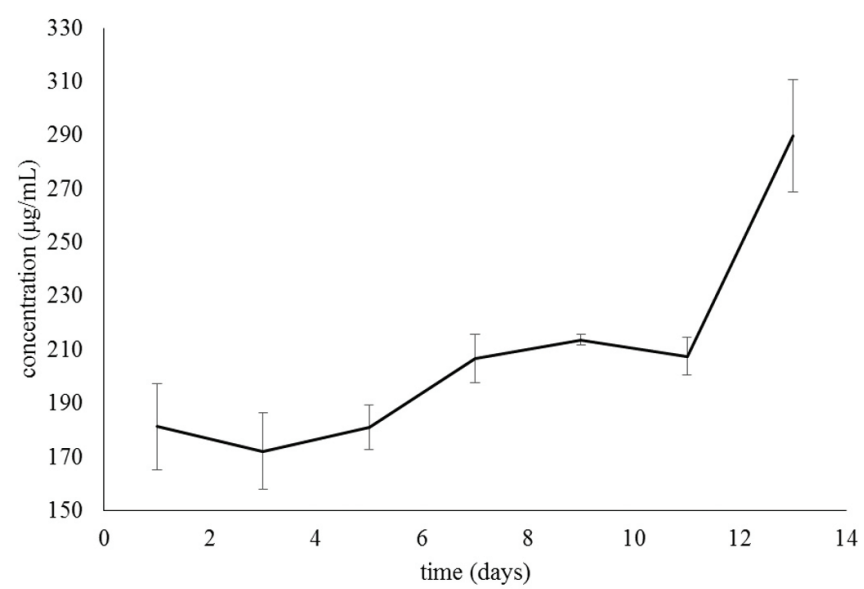

Figure 3. Peptide concentration of commercial fermented milk during 13 days of refrigerated storage (HPLC).

decisive in the formation of peptides (Donkor et al., 2007b), which was tested in this study (data not shown) through viable count.

The calculations of concentration performed show both appearance and disappearance of peptides, especially those of more than $4.5 \mathrm{kDa}$. A peptide of $7.86 \mathrm{kDa}$ appeared on the first and last days of refrigerated storage (Table 1). Similarly, a peptide of $5.62 \mathrm{kDa}$ appeared only on day 3 , and another one of $6.21 \mathrm{kDa}$ reached maximum concentration $(30.4 \mathrm{mg} / \mathrm{mL})$ on day 13. Furthermore, a peptide of $4.5 \mathrm{kDa}$ showed unstable behavior since its concentration increased and decreased frequently during the study. This peptide was observed throughout the entire refrigerated storage period. This behavior may have occurred due to the fact that these peptides are the source of formation of lower molecular weight peptides (Gasson \& de Vos, 1994).

Peptide concentration was analyzed by groups of molecular weight: greater than $4.5 \mathrm{kDa}$, between 2 and $4.5 \mathrm{kDa}$, and smaller than $2 \mathrm{kDa}$ (Figure 4). It was observed that the concentration of peptides in the first group was the lowest. This group also showed a varied behavior with a constant concentration on day 7 and increases and decreases 
González-Olivares et al.

Table 1. Size of peptides found and their variation over refrigerated storage of commercial fermented milk at $4^{\circ} \mathrm{C}$.

\begin{tabular}{|c|c|c|c|c|c|c|c|}
\hline \multirow{2}{*}{$\begin{array}{l}\text { Molecular weight } \\
\mathrm{kDa}\end{array}$} & \multicolumn{7}{|c|}{ Presence of peptides over refrigerated storage } \\
\hline & Day 1 & Day 3 & Day 5 & Day 7 & Day 9 & Day 11 & Day 13 \\
\hline 7.86 & $\mathrm{P}^{0}$ & $\mathrm{~A}$ & A & $\mathrm{A}$ & $\mathrm{A}$ & $\mathrm{A}$ & $\mathrm{P}(+)^{*}$ \\
\hline 6.21 & A & $\mathrm{P}^{0}$ & $\mathrm{P}(+)$ & A & $\mathrm{P}(-)$ & $\mathrm{P}(=)$ & $\mathrm{P}(+)^{*}$ \\
\hline 4.55 & $\mathrm{P}$ & $\mathrm{P}(-)^{0}$ & $\mathrm{P}+$ & $\mathrm{P}(+)^{*}$ & $\mathrm{P}(=)$ & $\mathrm{P}(-)$ & $\mathrm{P}(+)$ \\
\hline 3.86 & $\mathrm{P}$ & $\mathrm{P}(=)$ & $\mathrm{P}(=)$ & $\mathrm{P}(-)^{0}$ & A & $\mathrm{P}(+)$ & $\mathrm{P}(+)^{*}$ \\
\hline 1.61 & $\mathrm{~A}$ & $\mathrm{P}$ & $\mathrm{P}(+)$ & $\mathrm{P}(-)^{0}$ & $\mathrm{P}(+)$ & $\mathrm{P}(+)^{*}$ & $\mathrm{P}(-)$ \\
\hline 1.43 & $\mathrm{P}^{*}$ & $\mathrm{P}(-)^{0}$ & $\mathrm{P}(=)$ & $\mathrm{P}(+)$ & $\mathrm{P}(-)$ & $\mathrm{A}$ & $\mathrm{P}(-)$ \\
\hline 1.14 & $\mathrm{P}^{*}$ & $\mathrm{P}(-)$ & $\mathrm{P}(=)$ & $\mathrm{P}(=)$ & $\mathrm{P}(+)$ & $\mathrm{P}(-)^{0}$ & $\mathrm{P}(+)$ \\
\hline 0.87 & $\mathrm{P}$ & $\mathrm{P}(-)$ & $\mathrm{P}(+)$ & $\mathrm{P}(+)$ & $\mathrm{P}(-)^{0}$ & $\mathrm{P}(+)$ & $\mathrm{P}(+)^{*}$ \\
\hline
\end{tabular}

P:presence, A:absence, (-)Decreased concentration compared to the preceding measurement, $(+)$ Increased concentration compared to the preceding measurement, $(=)$ Same concentration compared to the preceding measurement, ${ }^{0}$ Lower concentration, ${ }^{*}$ Higher concentration.

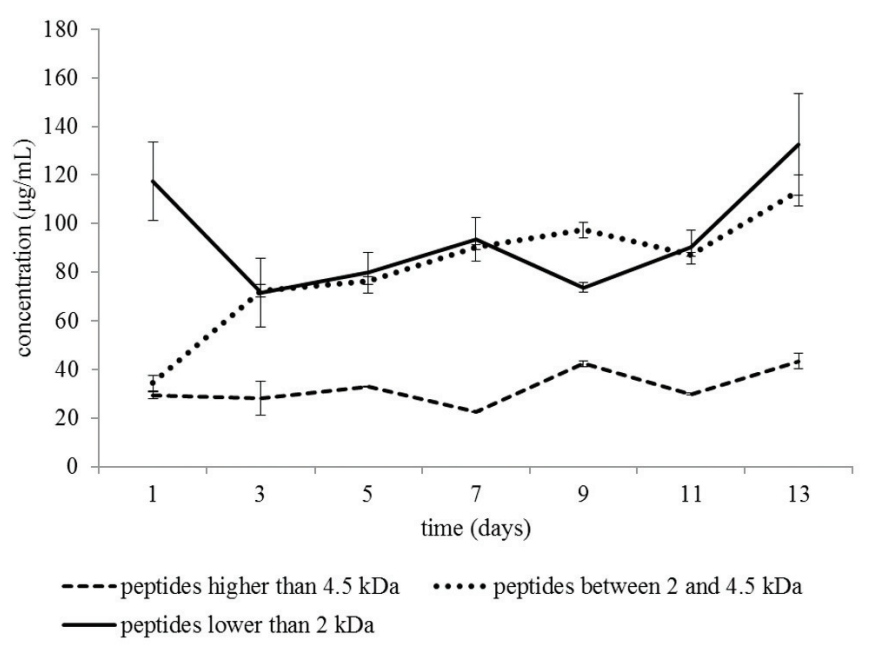

Figure 4. Protein concentration of commercial fermented milk under refrigerated storage in molecular weight groups.

up to the end of the refrigerated storage period. With respect to the second group, the concentrations increased on days $3,7,9$, and 13. The third group exhibited behavior similar to that of the second group; however, there was a significant decrease $(P=0.05)$ in the concentration from days 7 to 9 . This group showed a significant increase in the concentration at the end of the experiment and had the highest concentration. Gasson \& de Vos (1994) have reported that the formation of low molecular weight peptides during fermentation follows a cascade pattern. In this model, the source for the formation of high molecular weight peptides are proteins; the substrate for the intermediate molecular weight peptides are peptides of high molecular weight; and finally, they are the substrate for low molecular weight peptides. Similarly, it has been reported that the proteolytic system of LAB is associated with the accumulation of peptides of different sizes and types, depending on the nutritional needs of each LAB (Poolman et al., 1995). With regard to the proteolytic system of $L A B$, the optimum temperature of peptidases and proteinases ranges between 25 and $37^{\circ} \mathrm{C}$ (Juille et al., 2005).
However, it was found that their activity continues even under refrigeration since these enzymes remain breaking proteins and releasing peptides (Nielsen et al., 2009; Nighswonger et al., 1996).

Peptide separation was performed by chromatography using three different wavelengths: $210 \mathrm{~nm}$ for determination of peptide bonds, $257 \mathrm{~nm}$ for the determination of residues with phenylalanine (Phe), and $280 \mathrm{~nm}$ for tyrosine (Tyr) and tryptophan (Trp) residues (Creighton, 1990). During separation, more peptides with Phe residues than peptides with Tyr and Trp residues were detected. It was also observed that the peptides showing absorption at $280 \mathrm{~nm}$ had molecular weights of less than $3 \mathrm{kDa}(2.9,1.3$ and $0.87 \mathrm{kDa})$. It is known that the concentration and amino acid characteristics of the peptides released depend on the specificity of the enzymes in the proteolytic system of LAB (Marshall \& Tamime, 1997). Furthermore, it has been reported that the hydrophobic character of peptides promotes ACE inhibitory activity (Saito, 2008). Moreover, the importance of the presence of aromatic amino acids has been highlighted, especially phenylalanine with proline in peptides with high ACE inhibitory activity in ending C-terminal (Rojas-Ronquillo et al., 2012; Wu \& Ding, 2001; Iroyukifujita et al., 2000; Matsumura et al., 1993; Miyoshi et al., 1991).

\section{Conclusions}

It was determined that the accumulation of low molecular weight peptides in refrigerated commercial fermented milk follows a cascade pattern. This could be due to the effect of proteinases and peptidases of the proteolytic system on lactic acid bacteria, which promote the formation and accumulation of low molecular weight peptides.

The aromatic amino acids in the peptide fractions obtained increase the likelihood of finding peptides with antihypertensive activity in refrigerated commercial fermented milk since several authors have proven the importance of aromatic amino acids in peptides showing that function. 


\section{Acknowledgements}

The authors wish to acknowledge the financial support provided by PROMEP (Programa al Mejoramiento del Profesorado, Mexico).

\section{References}

Adhikari, K., Mustapha, A., Grün, I. U., \& Fernando, L. (2000). Viability of microencapsulated bifidobacteria in set yogurt during refrigerated storage. Journal of Dairy Science, 83(9), 1946-1951. http://dx.doi. org/10.3168/jds.S0022-0302(00)75070-3. PMid:11003222

Bomba, A., Brandeburová, A., Ricanyová, J., Strojny, L., Chmelárová, A., Szabadosová, V., Pramuková, B., Zofcáková, J., Salaj, R., Supuková, A., \& Cokasová, D. (2012). The role of probiotics and natural bioactive compounds in modulation of the commoc molecular pathways in phatogenesis of aterosclerosis and cancer. Biologia, 67(1), 1-13. http://dx.doi.org/10.2478/s11756-011-0155-6.

Cheung, H. S., Wang, F. L., Ondetti, M. A., Sabo, E. F., \& Cushman, D. W. (1980). Binding of peptides substrates and inhibitors of angiotensinconverting enzyme: importance of the $\mathrm{COOH}$-terminal dipeptide sequence. The Journal of Biological Chemistry, 255(2), 401-407. PMid:6243277.

Contreras, M., Carrón, R., Montero, M. J., Ramos, M., \& Recio, I. (2009). Novel-casein derived peptides with antihypertensive activity. International Dairy Journal, 19(10), 566-573. http://dx.doi. org/10.1016/j.idairyj.2009.05.004.

Creighton, T. E. (1990). Protein folding. The Biochemical Journal, 270(1), 1-16. PMid:2204340.

Donkor, O. N., Henriksson, A., Vasiljevic, T., \& Shah, N. P. (2006). Effect of acidification on the activity of probiotics in yogurt during cold storage. International Dairy Journal, 16(10), 1181-1189. http:// dx.doi.org/10.1016/j.idairyj.2005.10.008.

Donkor, O. N., Henriksson, A., Vasiljevic, T., \& Shah, N. P. (2007a). ACE-inhibitory activity of probiotic yogurt. International Dairy Journal, 17(11), 1321-1331. http://dx.doi.org/10.1016/j. idairyj.2007.02.009.

Donkor, O. N., Nilmini, S. L. I., Stolic, P., Vasiljevic, T., \& Shah, N. P. (2007b). Survival and activity of selected probiotic organisms in set type yogurt during cold storage. International Dairy Journal, 17(6), 657-665. http://dx.doi.org/10.1016/j.idairyj.2006.08.006.

Figueroa-González, I., Hérnandez-Sánchez, H., Rodríguez-Serrano, G., Gómez-Ruiz, L., García-Garibay, M., \& Cruz-Guerrero, A. (2010). Antimicrobial effect of Lactobacillus casei strain Shirota co-cultivated with Escherichia coli UAM0403. Revista Mexicana de Ingeniería Química, 9(1), 11-16.

Gasson, M. J., \& de Vos, W. M. (1994). The proteolytic system of lactic acid bacteria. In M. J. Gasson \& W. M. de Vos (Eds.), Genetics and biotechnology of lactic acid bacteria (cap. 4, pp. 169-210). London: Blackie Academic \& Professional/Chapman \& Hall.

González-Olivares, L. G., Jiménez-Guzmán, J., Cruz-Guerrero, A., Rodríguez-Serrano, G., Gómez-Ruiz, L., \& García-Garibay, M. (2011). Liberación de Péptidos Bioactivos por Bacterias Lácticas en Leches Fermentadas Comerciales. Revista Mexicana de Ingeniería Química, 10(2), 179-188.

Gorbach, S. L. (2000). Probiotics and gastrointestinal health. The American Journal of Gastroenterology, 95(1, Suppl.), S2-S4. http:// dx.doi.org/10.1016/S0002-9270(99)00806-0. PMid:10634218

Hafeez, Z., Cakir-Kiefer, C., Roux, E., Perrin, C., Miclo, L., \& DaryMourot, A. (2014). Strategies of producing bioactive peptides from milk proteins to functionalize fermented products. Food
Research International, 63, 71-80. http://dx.doi.org/10.1016/j. foodres.2014.06.002.

Hartmann, R., \& Meisel, H. (2007). Food-derived peptides with biological activity: from research to food applications. Current Opinion in Biotechnology, 18(2), 163-169. http://dx.doi. org/10.1016/j.copbio.2007.01.013. PMid:17292602

Hempel, S., Newberry, S. J., Maher, A. R., Wang, Z., Miles, J. N. V., Shanman, R., Johnsen, B., \& Shekelle, P. G. (2012). Probiotics for the prevention and treatment of antibiotic-associated diarrhea: a systematic review and meta-analysis. Journal of the American Medical Association, 307(18), 1959-1969. http://dx.doi.org/10.1001/ jama.2012.3507. PMid:22570464

Iroyukifujita, H., Eiichiyokoyama, K., \& Yoshikawa, M. (2000). Classification and antihypertensive activity of angiotensin I-converting enzyme inhibitory peptides derived from food proteins. Journal of Food Science, 65(4), 564-569. http://dx.doi. org/10.1111/j.1365-2621.2000.tb16049.x.

Jiménez-Guzmán, J., Cruz-Guerrero, A. E., Rodríguez-Serrano, G., López-Munguía, A., Gómez-Ruiz, L., \& García-Garibay, M. (2002). Enhancement of lactase activity in milk by reactive sulfhydryl groups induced by heat treatment. Journal of Dairy Science, 85(10), 2497-2502. http://dx.doi.org/10.3168/jds.S0022-0302(02)74332-4. PMid:12416801

Juille, O., Le Bars, D., \& Juillard, V. (2005). The specificity of oligopeptide transport by Streptococcus thermophilus resembles that of Lactococcus lactis and not that of pathogenic streptococci. Microbiology, 151(Pt 6), 1987-1994. http://dx.doi.org/10.1099/ mic.0.27730-0. PMid:15942005

Laemmli, U. K. (1970). Cleavage of structural proteins during the assembly of the head of bacteriophage T4. Nature, 227(5259), 680685. http://dx.doi.org/10.1038/227680a0. PMid:5432063

Marshall, V. W., \& Tamime, A. Y. (1997). Starter cultures employed in the manufacture of biofermented milks. International Journal of Dairy Technology, 50(1), 35-41. http://dx.doi. org/10.1111/j.1471-0307.1997.tb01733.x.

Matsumura, N., Fujii, M., Takeda, Y., \& Shimizu, T. (1993). Isolation and characterization of angiotensin I-converting enzyme inhibitory peptides derived from bonito bowels. Bioscience, Biotechnology, and Biochemistry, 57(10), 1743-1744. http://dx.doi.org/10.1271/ bbb.57.1743. PMid:7764272

Meisel, H. (2005). Biochemical properties of peptides encrypted in bovine milk proteins. Current Medicinal Chemistry, 12(16), 1905-1919. http://dx.doi.org/10.2174/0929867054546618. PMid:16101509

Meisel, H., \& Bockelmann, W. (1999). Bioactive peptides encrypted in milk proteins: proteolytic activation and thropho-functional properties. Antonie van Leeuwenhoek, 76(1-4), 207-215. http:// dx.doi.org/10.1023/A:1002063805780. PMid:10532380

Miyoshi, S., Ishikawa, H., Kaneko, T., Fukui, F., Tanaka, H., \& Maruyama, S. (1991). Structures and activity of angiotensinconverting enzyme inhibitors in an alpha-zein hydrolysate. Agricultural and Biological Chemistry, 55(5), 1313-1318. http:// dx.doi.org/10.1271/bbb1961.55.1313. PMid:1368684

Nagpal, R., Behare, P., Rana, R., Kumar, A., Kumar, M., Arora, S., Morotta, F., Jain, S., \& Yadav, H. (2011). Bioactive peptides derived from milk proteins and their health beneficial potentials: an update. Food \& Function, 2(1), 18-27. http://dx.doi.org/10.1039/c0fo00016g. PMid:21773582

Nakamura, Y., Yamamoto, N., Sakai, K., \& Takano, T. (1995). Antihypertensive effect of sour milk and peptides isolated from it that are inhibitors to angiotensin I-converting enzyme. Journal 
of Dairy Science, 78(6), 1253-1257. http://dx.doi.org/10.3168/jds. S0022-0302(95)76745-5. PMid:7673515

Nielsen, M. S., Martinussen, T., Flambard, B., Sorensen, K., \& Otte, J. (2009). Peptide profiles and angiotensine-I-converting enzyme inhibitory activity of fermented milk products: effect of bacterial strain, fermentation, $\mathrm{pH}$ and storage time. International Dairy Journal, 19(3), 155-165. http://dx.doi.org/10.1016/j. idairyj.2008.10.003.

Nighswonger, B. D., Brashears, M. M., \& Gilliland, S. E. (1996). Viability of Lactobacillus acidophilus and Lactobacillus casei in fermented milk products during refrigerated storage. Journal of Dairy Science, 79(2), 212-219. http://dx.doi.org/10.3168/jds.S00220302(96)76353-1. PMid:8708082

Ortiz-Chao, P., Gómez-Ruiz, J. A., Rastall, R. A., Mills, P., Cramer, R., Pihlanto, A., Korhonen, H., \& Jauregi, P. (2009). Production of novel ACE inhibitory pepetides from $\beta$-lactoglobulin usin protease N-amano. International Dairy Journal, 19(2), 69-76. http://dx.doi. org/10.1016/j.idairyj.2008.07.011.

Phelan, M., Aherne, A., Fitzgerald, R., \& O’Brien, N. (2009). Caseinderived bioactive peptides: biological effects, industrial uses, safety aspects and regulatory status. International Dairy Journal, 19(11), 643-654. http://dx.doi.org/10.1016/j.idairyj.2009.06.001.

Poolman, B., Kunji, E. R. S., Hagting, A., Juillard, V., \& Konings, W. N. (1995). The proteolytic pathway of Lactococcus lactis. Society for Applied Bacteriology Symposium Series, 24, 65S-75S. PMid:7570167.

Quirós, A., Hernández-Ledesma, B., Ramos, M., Amigo, L., \& Recio, I. (2005). Angiotensin-converting enzyme inhibitory activity of peptides derived from caprine kefir. Journal of Dairy Science, 88(10), 3480-3487. http://dx.doi.org/10.3168/jds.S0022-0302(05)73032-0. PMid:16162521

Roberfroid, M. B. (2000). Prebiotics and probiotics: are they functional foods? The American Journal of Clinical Nutrition, 71(6, Suppl.), 1682S-1687S, discussion 1688S-1690S. PMid:10837317.

Rojas-Ronquillo, R., Cruz-Guerrero, A., Flóres-Nájera, A., RodríguezSerrano, G., Gómez-Ruiz, L., Reyes-Grajeda, J. P., Jiménez-Guzmán, J., \& García-Garibay, M. (2012). Antithrombotic and angiotensinconverting enzyme inhibitory properties of peptides released from bovine casein by Lactobacillus casei Shirota. International Dairy Journal, 26(2), 147-154. http://dx.doi.org/10.1016/j. idairyj.2012.05.002.
Saito, T. (2008). Antihypertensive peptides derived from bovine casein and whey proteins. Advances in Experimental Medicine and Biology, 606, 295-317. http://dx.doi.org/10.1007/978-0-387-74087-4_12. PMid:18183935

Savijoki, K., Ingmer, H., \& Varmanen, P. (2006). Proteolytic systems of lactic acid bacteria. Applied Microbiology and Biotechnology, 71(4), 394-406. http://dx.doi.org/10.1007/s00253-006-0427-1. PMid:16628446

Stanton, C., Ross, R. P., Fitzgerald, G. F., \& Van Sinderen, D. (2005). Fermented functional foods based on probiotics and their biogenic metabolites. Current Opinion in Biotechnology, 16(2), 198-203. http://dx.doi.org/10.1016/j.copbio.2005.02.008. PMid:15831387

Takano, T. (1998). Milk derived peptides and hypertension reduction. International Dairy Journal, 8(5-6), 375-381. http://dx.doi. org/10.1016/S0958-6946(98)00060-0.

Udenigwe, C. C., \& Aluko, R. E. (2012). Food protein-derived bioactive peptides: production, processing, and potential health benefits. Journal of Food Science, 77(1), R11-R24. http://dx.doi.org/10.1111/ j.1750-3841.2011.02455.x. PMid:22260122

Vinderola, C. G., Bailo, N., \& Reinheimer, J. A. (2000). Survival of probiotic microflora in Argentinian yoghurts during refrigerated storage. Food Research International, 33(2), 97-102. http://dx.doi. org/10.1016/S0963-9969(00)00011-9.

Vinderola, C. G., Mocchiutti, P., \& Reinheimer, J. A. (2002). Interactions among lactic acid starter and probiotic bacteria used for fermented dairy products. Journal of Dairy Science, 85(4), 721-729. http:// dx.doi.org/10.3168/jds.S0022-0302(02)74129-5. PMid:12018416

Wu, J., Aluko, R. E., \& Nakai, S. (2006). Structural requirements of Angiotensin I-converting enzyme inhibitory peptides: quantitative structure-activity relationship study of di- and tripeptides. Journal of Agricultural and Food Chemistry, 54(3), 732-738. http://dx.doi. org/10.1021/jf051263l. PMid:16448176

Wu, J., \& Ding, X. (2001). Hypotensive and physiological effect of angiotensin converting enzyme inhibitory peptides derived from soy protein on spontaneously hypertensive rats. Journal of Agricultural and Food Chemistry, 49(1), 501-506. http://dx.doi.org/10.1021/ jf000695n. PMid:11170618

Yerlikaya, O. (2014). Starter cultures used in probiotic dairy product preparation and popular probiotic dairy drinks. Food Science and Technology, 34(2), 221-229. 